\title{
Circulation of hantaviruses in the influence area of the Cuiabá-Santarém Highway
}

\author{
Daniele BA Medeiros ${ }^{1}$, Elizabeth S Travassos da Rosa', Aparecido AR Marques ${ }^{2}$, \\ Darlene B Simith', Adriana R Carneiro', Jannifer O Chiang1', Ivy TE Prazeres', \\ Pedro FC Vasconcelos ${ }^{1 /+}$, Márcio RT Nunes ${ }^{1}$
}

\footnotetext{
${ }^{1}$ Seção de Arbovirologia e Febres Hemorrágicas ${ }^{3}$ Laboratório de Biologia Molecular e Sorologia, Instituto Evandro Chagas, Rodovia BR-316 Km 7, 67030-000 Ananindeua, PA, Brasil ²Secretaria de Saúde do Estado do Mato Grosso, Cuiabá, MT, Brasil
}

We describe evidence of circulation of hantaviruses in the influence area of the Santarém-Cuiabá Highway (BR-163) in the Brazilian Amazon through the prevalence of specific antibodies against hantaviruses in inhabitants living in four municipalities of this area: Novo Progresso (2.16\%) and Trairão (4.37\%), in state of Pará (PA), and Guarantã do Norte (4.74\%) and Marcelândia (9.43\%), in state of Mato Grosso. We also demonstrate the ongoing association between Castelo dos Sonhos virus (CASV) and hantavirus pulmonary syndrome (HPS) cases in the Castelo dos Sonhos district (municipality of Altamira, PA) and the first report of CASV in the municipalities of Novo Progresso and Guarantã do Norte. The results of this work highlight the risk for a possible increase in the number of HPS cases and the emergence of new hantavirus lineages associated with deforestation in this Amazonian area after the conclusion of paving works on BR-163 Highway.

Key words: hantaviruses - Amazon - BR-163 Highway

Hantaviruses are the etiologic agents of the hantavirus pulmonary syndrome (HPS), a group of RNA viruses belonging to the family Bunyaviridae, genus Hantavirus (ICTV 2005). These viruses are transmitted to humans by inhalation of infected aerosols produced by dried wild rodent excrement (family Cricetidae: subfamily Sigmodontinae) (Lee et al. 1981, OPAS 1999, Nichol 1999, Figueiredo et al. 2001).

The hantavirus genome consists of a tripartite negative-sense RNA, denoted as small, medium or large, which encodes the nucleocapsid $(\mathrm{N})$ protein, two envelope glycoproteins ( $\mathrm{Gn}$ and $\mathrm{Gc}$ ) and the viral polymerase, respectively (ICTV 2005).

The disease has been considered an important public health problem in the New World since 1993, due to the high fatality rate associated with it (LeDuc et al. 1985, 1986, Nichol et al. 1993, Iversson et al. 1994, Rosa et al. 2005, MS/SVS 2006).

In Brazil, since the first cases of HPS were reported in Juquitiba (in 1993), state of São Paulo (SP), Southeastern Brazil (Iversson et al. 1994) and Castelo dos Sonhos, a district of Altamira municipality, state of Pará (PA), Northern Brazil (in 1995) (Johnson et al. 1999), approximately 1,209 cases of HPS were reported as of Decem-

Financial support: CNPq (MCT-CNPq/MS-SCTIE-DECIT 34/2005) INCT/MCT/CNPq/FAPESPA (573739/2008-0 300.460/2008-1), IEC/ SVS/MS

+ Corresponding author: pedrovasconcelos@iec.pa.gov.br

Received 13 November 2009

Accepted 1 April 2010 ber 31, 2008. Of these, $20.7 \%(\mathrm{n}=232)$ occurred in the Brazilian Amazon region, mainly in the states of Mato Grosso (MT) and PA; however, the states of Amazonas (AM), Rondônia (RO) and Maranhão (MA) have also reported HPS cases. Furthermore, some municipalities in those states located in the influence area of the BR-163 Highway have already registered cases of HPS, such as the municipalities of Maués (AM), Altamira (districts of Castelo dos Sonhos and Cachoeira da Serra) and Novo Progresso (PA) and Marcelândia, União do Sul and Peixoto de Azevedo (MT), where the occurrence of cases in newly occupied areas has increased each year (MS/SVS 2006). Although the disease is severe, little is known about either the hantavirus species associated with HPS transmission to humans or the identity of the rodent reservoirs. Thus, this work describes new seroepidemiological information and the molecular characterisation of hantavirus lineages associated with HPS cases in the BR-163 Highway influence area, based on data obtained during field collections performed in four distinct localities of PA and MT in a longitudinal study, before the conclusion of its construction.

\section{SUBJECTS, MATERIALS AND METHODS}

Study area - Four study sites were selected along the Cuiabá-Santarém Highway (BR-163). Two of them were located in PA, the municipalities of Trairão (04 $34^{\circ}$ 'S $\left.55^{\circ} 56^{\prime} \mathrm{W}\right)$ and Novo Progresso $\left(07^{\circ} 08^{\prime} \mathrm{S} 55^{\circ} 22^{\prime} \mathrm{W}\right)$ and the other two were located in MT, the municipalities of Guarantã do Norte $\left(09^{\circ} 47^{\prime} \mathrm{S} 54^{\circ} 55^{\prime} \mathrm{W}\right)$ and Marcelândia $\left(11^{\circ} 08^{\prime} \mathrm{S} 54^{\circ} 36^{\prime} \mathrm{W}\right)$ (Fig. 1).

Serological investigation in the four sites - For serologic studies, a total of 2,737 blood samples were collected from people living at the four study sites: Trairão 
( $n=686)$, Novo Progresso $(n=740)$, Marcelândia $(n=721)$ and Guarantã do Norte $(n=590)$. Collection of blood specimens was carried out during three distinct seasonal periods in 2006: the period between dry and rainy seasons (April/May); dry season (August/September) and rainy season (November/December). Approximately 8-10 $\mathrm{mL}$ of blood were collected from patients clinically suspected of HPS and/or with undifferentiated febrile illness who spontaneously visited local Health Care Units as well as by active surveillance in the human dwellings. Blood samples were also collected from asymptomatic subjects living in local communities of the four municipalities. All participants were in agreement with the study and provided informed consent before sample collection. At the time of sample collection, activities that could lead to the risk of hantavirus infections were observed and analyzed together with epidemiological formularies used for HPS investigation, as determined by

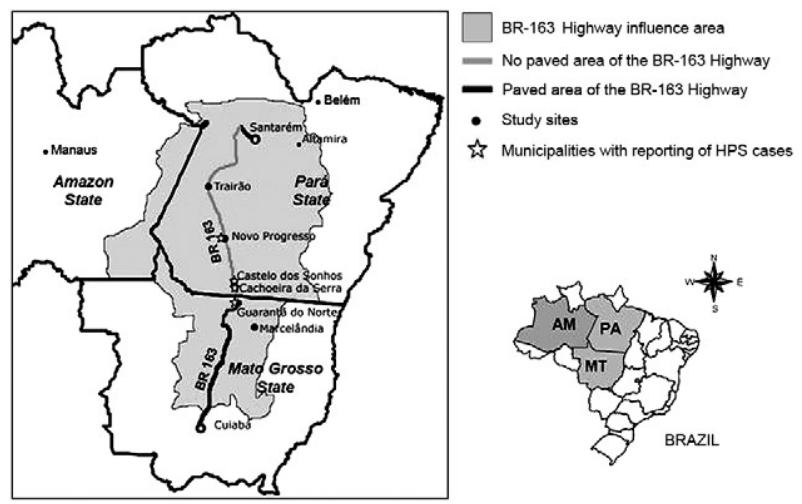

Fig. 1: map of the Amazon region, evidencing the states of Pará (PA) and Mato Grosso (MT) and showing the BR-163 Highway, which connects the municipality of Santarém, in PA, with Cuiabá, the capital of MT. The four study sites are shown (municipalities of Trairão, Novo Progresso, Guarantã do Norte and Marcelândia), as well as the cities where registered cases of hantavirus pulmonary syndrome (HPS) were used in the molecular study: Castelo dos Sonhos and Cachoeira da Serra, district from municipality of Altamira, Novo Progresso and Guarantã do Norte (»). the Brazilian Health Surveillance Department/Ministry of Health (MS/SVS 2006). This study was approved by the Instituto Evandro Chagas Ethical Committee.

For the detection of hantavirus antibodies in human serum samples, IgM and IgG ELISA assays were performed using the $\mathrm{N}$ recombinant antigen produced for the Andes virus (Padula et al. 2000) adapted to the Ksiazek protocol (CDC/Atlanta). All samples were screened by IgG ELISA and the positive ones were later tested for the detection of IgM by ELISA.

RNA extraction and genome amplification - For the molecular study, samples from eight patients clinically suspected of having HPS with laboratory confirmation by serology (IgM positive) were selected (Table I). These samples were sent to the Evandro Chagas Institute by the municipal and/or state general offices of health during the execution of the project (2006-2008) and two samples, H 716591 and H 708928, were collected during the expedition to the sites in the municipalities of Novo Progresso and Guarantã do Norte, respectively.

Viral RNA was extracted directly from blood and/or serum using the QIAamp Viral RNA Mini kit (Qiagen, Valencia, CA) according to the manufacturer's instructions. The hantavirus genome was obtained through amplification with a two-step reverse-transcription polymerase chain reaction (RT-PCR) followed by a Nested-PCR step, as previously described by Johnson et al. (1997) and adapted by Rosa et al. (2005). First, the RT step was performed in a $10 \mu \mathrm{L}$ reaction mixture containing $5 \mu \mathrm{L}(1-5 \mathrm{ng})$ of viral RNA, $10 \mu \mathrm{M}$ of the reverse primer (SS143C), 1X RT buffer $(250 \mathrm{mM}$ Tris- $\mathrm{HCl} \mathrm{pH} 8.3,375 \mathrm{mM} \mathrm{KCl}, 15 \mathrm{mM} \mathrm{MgCl}$ ); DTT [1 mM - 0.01\% (v/v) NP-40, 50\% (v/v) glycerol], $2.5 \mathrm{mM}$ dithiothreitol, 20 U of RNAsin RNase inhibitor (Invitrogen, Carlsbad, CA) and $1 \mu \mathrm{L}$ of Superscrit ${ }^{\mathrm{TM}}$ II Reverse Transcriptase (Invitrogen, Carlsbad, CA). The PCR was carried out in a $25 \mu \mathrm{L}$ reaction mixture containing $5 \mu \mathrm{L}$ viral cDNA from RT reaction, $10 \mu \mathrm{M}$ of the SS143C and SS1070R primers, 1X PCR buffer $(0.4 \mathrm{mM}$ of DNTPs, $2.4 \mathrm{mM} \mathrm{MgSO}_{4}$ ) and $0.5 \mu \mathrm{L} \mathrm{Platinum}^{\circledR}$ Taq Mix (Invitrogen, Carlsbad, CA). The RT reaction was first performed for $90 \mathrm{~min}$ at $42^{\circ} \mathrm{C}$, followed by $35 \mathrm{PCR}$ cycles, each composed of steps at $94^{\circ} \mathrm{C}$ for $45 \mathrm{~s}, 45^{\circ} \mathrm{C}$ for $1 \mathrm{~min}$ and

TABLE I

Samples diagnosed as hantavirus pulmonary syndrome cases used in the molecular study

\begin{tabular}{lcccccc}
\hline State & Municipality/district & Patient & Sex & Age & Sample & Date of samples collection \\
\hline Pará & Novo Progresso & H 708928 & F & 25 & serum & 5 Jun 2006 \\
Pará & Novo Progresso & H 745332 & M & 53 & blood & 15 Mar2008 \\
Pará & Novo Progresso & H 745427 & M & 39 & blood & 10 Apr 2008 \\
Pará & Altamira/Castelo dos Sonhos & H 714214 & F & 32 & serum & 6 Aug 2006 \\
Pará & Altamira/Castelo dos Sonhos & H 695323 & M & 24 & serum & 14 Sep 2005 \\
Pará & Altamira/Castelo dos Sonhos & H 700306 & M & 30 & serum & 9 Feb 2006 \\
Pará & Altamira/Cachoeira da Serra & H 712177 & M & 36 & serum & 17 Aug 2006 \\
Mato Grosso & Guarantã do Norte & H 716591 & M & 29 & serum & 20 Nov 2006
\end{tabular}


$72^{\circ} \mathrm{C}$ for $2 \mathrm{~min}$. A final extension step at $72^{\circ} \mathrm{C}$ for $10 \mathrm{~min}$ was used to complete the extension. The Nested-PCR reaction was performed in a $100 \mu \mathrm{L}$ mixture reaction, using the same protocol as the PCR step but substituting the primers for SS283C and PPT7716R and adding $10 \mu \mathrm{L}$ of the cDNA from PCR step (diluted 1:20).

Nucleotide sequencing - The obtained amplicons (434 bp) were purified by the GFXTM PCR DNA and Gel Band Purification kit (GE healthcare). They were then directly sequenced in both directions using an automated sequencer ABI 377 (Applied Biosystems), the ABI Prism Dye Terminator Kit (Applied Biosystems) and the dideoxiterminator method (Sanger et al. 1977).

Sequence analysis and phylogeny - The obtained sequences were initially inspected for quality by the software SeqMan v.5.03 ${ }^{\circ}$ (DNA Star Inc). Phylogenetic trees were constructed by the neighbour joining (NJ) (Saitou \& Nei 1987), maximum likelihood (ML) and maximum parsimony (MP) methods in the PAUP 4.0b10 (Swofford 2003). The program Modeltest version 3.6 (Posada \& Crandall 1998) was used to determine which model of nucleotide substitution best explained the data using Akaike information criterion. For the NJ analysis, a distance matrix was calculated from the aligned sequences using the Tamura-3 parameter model with a different gamma distribution parameter (gamma pa- rameter $=1.0)$. For the MP analysis, a transition/transversion rate of 4:1 was used. Bootstrap analyses (1,000 replicates) were implemented to place confidence values on phylogenetic groupings (Felsenstein 1985). Bayesian analysis with Markov chain Monte Carlo sampling was performed with MrBayes 3.0b4 run for two million generations and sampling on every 1,000 trees. Bayesian posterior probabilities were estimated on a $50 \%$ majority rule consensus after burn-in (Huelsenbeck et al. 2001). The TRACER program (evolve.zoo.ox.ac.uk) was used to verify if the MrBayes runs reached the appropriate convergence. Hantaviruses from the Old World were used as an out-group to give confidence on groupings.

\section{RESULTS}

Surveillance of hantavirus antibodies in the studied populations - A summary of main epidemiologic results of the four sites are presented in Table II.

Municipality of Novo Progresso - A total of 740 serum samples were collected from individuals residing in this site, corresponding to $1.89 \%$ of the estimated population $(\mathrm{n}=39,245$ inhabitants) (Nunes et al. 2009). Of these, 318 (43\%) were male, with ages ranging from $2-75$ years, with a mean of 24.1 years (median of 18 years); 422 (57\%) were female, with ages ranging from 4-73 years, with a mean of 21.6 years (median of 16 years). Most of the male partici-

TABLE II

Hantavirus seroepidemiologic data from the four study sites in BR-163 Highway area

\begin{tabular}{|c|c|c|c|c|}
\hline \multirow[t]{2}{*}{ State } & \multicolumn{2}{|c|}{ Pará } & \multicolumn{2}{|c|}{ Mato Grosso } \\
\hline & Novo Progresso & Trairão & Guarantã do Norte & Marcelândia \\
\hline Total of sample & 740 & 686 & 590 & 721 \\
\hline Male n (\%) & $318(43)$ & $267(38.9)$ & $226(38.3)$ & $221(30.6)$ \\
\hline Female n $(\%)$ & $422(57)$ & $419(61.1)$ & $364(61.7)$ & $500(69.4)$ \\
\hline $\begin{array}{l}\text { Total of samples IgG positive } \\
\text { (positive percept) } n(\%)\end{array}$ & $16(2.16)$ & $30(4.3)$ & $28(4.75)$ & $68(9.43)$ \\
\hline \multirow{3}{*}{ 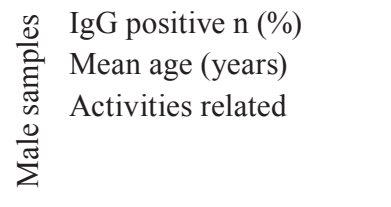 } & $7(43.75)$ & $17(56.7)$ & $8(29.7)$ & $22(32.3)$ \\
\hline & 30.1 & 32.8 & 61.3 & 44 \\
\hline & $\begin{array}{l}\text { child and young students, } \\
\text { agriculture worker }\end{array}$ & $\begin{array}{c}\text { agriculture worker, } \\
\text { hunting, } \\
\text { wood extraction }\end{array}$ & $\begin{array}{l}\text { agriculture worker, } \\
\text { bricklayer }\end{array}$ & $\begin{array}{c}\text { agriculture, } \\
\text { wood extraction, } \\
\text { local commerce }\end{array}$ \\
\hline \multirow{3}{*}{ 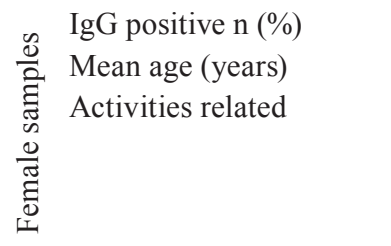 } & $6(37.5)$ & $13(43.3)$ & $19(70.3)$ & $46(67.7)$ \\
\hline & 28.7 & 37.5 & 33.9 & 37.1 \\
\hline & $\begin{array}{l}\text { young students, } \\
\text { mineral extraction, } \\
\text { agriculture worker, } \\
\text { wood extraction }\end{array}$ & $\begin{array}{c}\text { agriculture worker, } \\
\text { house owner activities }\end{array}$ & $\begin{array}{l}\text { agriculture worker, } \\
\text { house owner, } \\
\text { student }\end{array}$ & $\begin{array}{c}\text { domestic, } \\
\text { agriculture worker }\end{array}$ \\
\hline Sample IgM positive & 3 & 1 & 1 & 1 \\
\hline Symptomatic & 2 ( 1 male and 1 female) & 0 & 0 & 0 \\
\hline Asymptomatic & 1 (male) & 1 & 1 & 1 \\
\hline
\end{tabular}


pants were adults ( $>18$ years old), while most individuals in the female population were children and young adults (between 10-18 years old). The most frequent activities reported in this municipality were agriculture and livestock ( $\mathrm{n}=78,10.54 \%)$, wood extraction $(\mathrm{n}=47$; $6.65 \%)$, mineral extraction $(\mathrm{n}=10 ; 1.35 \%)$, housework $(\mathrm{n}=70 ; 9.46 \%)$ and other activities related to commerce and public service $(16.6 \%)$ or study $(n=410 ; 55.4 \%)$. Sixteen $(2.16 \%)$ serum samples were positive for hantavirus $\mathrm{IgG}$ antibodies. Of these, six were from female individuals $(37.5 \%)$ with a mean age of 28.7 years, collected from two $(33.3 \%)$ young students and from four (66.7\%) adults with jobs related to mineral extraction, agriculture and wood extraction. Seven were male $(43.75 \%)$ with a mean age of 30.1 years: one child (14.28\%), two young students $(28.57 \%)$ and four $(57.15 \%)$ agriculture workers. Three out of the 16 individuals $(18.75 \%)$ were also positive for hantaviral anti-IgM: one asymptomatic adult woman, who reported to work at a mineral extraction area, one oligosymptomatic young male agriculture worker, who reported fever, headache, chills and epigastric manifestations and one elderly woman, with a classical HPS presentation with evolution to the cardiopulmonary phase (H 708928). Correlation between IgG or IgM positive samples and the collection period was not observed.

Municipality of Trairão - A total of 686 samples were collected in this municipality (4.26\% of 16,097 inhabitants) (Nunes et al. 2009). The sample pool included 267 (38.9\%) obtained from male individuals and 419 (61.1\%) from females. Among the male individuals, the mean age was 28.5 years and the majority of them $(n=190$; $71.16 \%$ ) were considered adults (ages $\geq 18$ years), while the female population presented a mean age of 31.6 years and ranged from 2-89 years (median of 28 years). Most females $(\mathrm{n}=323 ; 77.1 \%)$ included were adults as well ( $\geq 18$ years old). The main economic activities reported by the individuals were agriculture $(\mathrm{n}=154 ; 22.45 \%)$, housework $(\mathrm{n}=194 ; 57.27 \%)$, public service $(\mathrm{n}=45$; $13.93 \%)$ and retired $(\mathrm{n}=22 ; 6.28 \%)$. A total of 30 out of $686(4.37 \%)$ individuals were positive for hantaviral $\mathrm{IgG}$ antibodies. Most of the IgG positive reactions were found in male individuals $(\mathrm{n}=17,56.7 \%)$, with a mean age of 32.8 years. Eight subjects $(47 \%)$ reported work activities associated with agriculture, hunting or wood extraction. Thirteen (43.3\%) were IgG positive females and nine $(69.23 \%)$ were adults with a mean age of 37.5 years who worked in agriculture or household chores. A single sample was IgM positive for hantavirus and was obtained from an asymptomatic retired male agriculture worker (59 years old). There was no correlation between $\mathrm{IgG} / \mathrm{IgM}$ seroprevalence and the collection period.

Municipality of Guarantã do Norte - At this site, a total of 590 samples were collected: 226 (38.3\%) were obtained from males and $364(61.7 \%)$ from females. These numbers represent about $1.92 \%$ of the municipality population ( $\mathrm{n}=30,754$ inhabitants) (Nunes et al. 2009). For male individuals, the age ranged from 1-43 years, with a mean age of 36.7 years (median of 36 years). Most of the individuals were considered adults, with ages $\geq 18$ years $(\mathrm{n}=186)$. Regarding the female population, the mean age was of 33.3 years, ranging from 3-77 years (median of 31 years). Activities reported were agriculture and livestock $(\mathrm{n}=83 ; 14.07 \%)$, housework $(\mathrm{n}=202 ; 34.24 \%)$, school $(\mathrm{n}=92 ; 15.6 \%)$ and other activities related to commerce and public service $(\mathrm{n}=172 ; 29.15 \%)$. A total of 28 individuals $(4.74 \%)$ were IgG positive for hantavirus. Nineteen were female $(70.3 \%)$, with a mean age of 33.9 years. The economic activities reported were agriculture $(n=2)$, housework $(n=6)$ and students $(n=7)$, among others. Nine were male, with a mean age of 61.3 years: three reported to be retired. Of the $\mathrm{IgG}$ positive samples, two were positive for IgM detection: an asymptomatic 72-year-old housewife and an adult male farmer, who presented with the clinical symptoms of HPS and an evolution to the cardiopulmonary phase (H 716591). Correlation between $\operatorname{IgG}$ or $\operatorname{IgM}$ positive results and the collection period was not observed.

Municipality of Marcelândia - A total of 721 samples were tested from this municipality, which represented $5.12 \%$ of its entire population ( $\mathrm{n}=14,084$ inhabitants) (Nunes et al. 2009). Of these, 221 (30.65\%) were from males with ages ranging from $11-80$ years (mean age of 37.7 years; median of 36 years) and 500 (69.35\%) were from females with ages ranging from 5-85 years (median of 31 years; mean age of 37.7 years). Most of the individuals were adults who reported economic activities, such as agriculture and livestock $(\mathrm{n}=137)$, wood extraction $(\mathrm{n}=17)$, housework $(\mathrm{n}=279)$ or student $(\mathrm{n}=77)$. A total of $68(9.43 \%)$ individuals were IgG-positive for hantavirus. Twenty-two were male (mean age of 44 years) and 46 were female (mean age of 37.1 years). It is interesting to note that among the IgG-positive individuals, 14 had activities related to agriculture, one performed wood extraction, 27 were housewives and the others had activities associated with local commerce, public service or were students. A single IgM positive reaction was detected in a blood serum of a 66-year-old asymptomatic farmer. Regarding the period of sample collection, most of the IgG samples $(\mathrm{n}=39 ; 57.35 \%)$ were collected in November/December, during the local rainy season.

Genetic characterisation of hantaviruses - The multiple sequencing alignments revealed high genetic similarity between the studied strains and the Castelo dos Sonhos virus (CASV) partial N gene sequence (98.3\%) available in the GenBank (AF307324) and with other Brazilian strains recently sequenced from HPS cases reported in Novo Progresso and Altamira (PA) as well as in Guarantã do Norte (MT).

The phylogenetic analysis using NJ, MP and ML showed similar topology (data not shown); however, the tree building by ML presents more reliable bootstrap values and was associated with posterior probabilities generated by the Bayesian method, as shown in Fig. 2. The comparative phylogeny depicted the hantaviruses in two major clusters: New World and Old World hantaviruses. The New World hantavirus cluster was subdivided into two clades (I and II) with a genetic distance of $28.2 \%$. Clade I included eight sub-clades: I-a (Hu39694, V strain South AH-1, Bermejo virus, Lechiguanas, Neembuco 

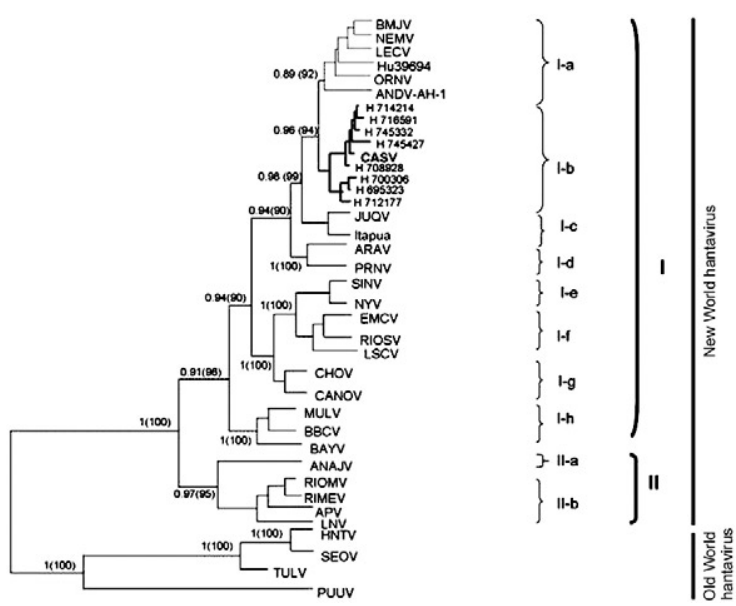

Fig. 2: phylogenetic tree of the partial small RNA segment of hantavirus lineages by maximum likelihood and Bayesian methods. Bootstrap (parenthesis) and posterior probabilities values were represented to each node. APV: Alto Paraguay; ANAJV: Anajatuba; ANDV-AH1: Hu39694 Andes south AH1; ARAV: Araraquara; BAYV: Bayou; BCCV: Black Creek Canal; BMJV: Bermejo; CANOV: Cano Delgadito; CASV: Castelo dos Sonhos; CHOV: Choclo; EMCV: El Moro Canyon; HNTV: Hantaan; JUQV: Juquitiba-Araucária; LECV: Lechiguanas; LNV: Laguna Negra; LSCV: Limestone Canyon; MULV: Muleshoe; NEMV: Neembuco; NYV: New York; ORNV: Oran; PRNV: Pergamino; PUUV: Puulmala; RIMEV: Rio Mearim; RIOMV: Rio Mamoré; RIOSV: Rio Segundo; SEOV: Seoul; SINV: Sin Nombre; TULV: Tula.

virus, Oran), I-b (CASV, related strains), I-c (Juquitiba/ Araucária virus, Itapuã virus), I-d (Araraquara virus, Pergamino virus), I-e (Sin Nombre virus, New York virus), I-f (Limestone Canyon virus, El Moro Canyon virus, Rio Segundo virus), I-g (Choclo virus, Caño Delgadito virus) and I-h (Muleshoe virus, Bayou virus, Black Creek Canal virus). Clade II (genetic divergence of $23.7 \%$ ) was subdivided into two subclades: subclade II-a, represented by the Anajatuba virus and subclade II-b, which grouped Rio Mamoré virus, Rio Mearim virus, Alto Paraguay virus and Laguna Negra virus. The studied strains were included in the lineage I-b1 and were more closely related to the CASV prototype strain.

\section{DISCUSSION}

The BR-163 Highway was constructed in 1973 and connects the municipalities of Cuiabá, capital of the MT in Central Brazil, to Santarém, the main port city in the delta of Tapajós River, PA. The influence area of the BR-163 Highway is represented by an area of 1.2 million square kilometres, comprising 71 different municipalities in the southeast of PA, southwest of AM and north of the MT, in the Brazilian Amazon. The BR-163 influence area corresponds to a total of $14.4 \%$ of the national territory and $20 \%$ of the Brazilian Amazon region. In this area, different quilombolas, urban and rural populations and more than 30 indigenous tribes, totalling approximately two million people, live and are sustained mainly by agriculture, wood extraction, vegetal extraction and cattle grazing activities (IBGE 2007).
The emergence of hantaviruses as a potential threat to public health in the influence area of the BR-163 Highway is remarkable. Since 1995, when the first HPS case was identified in Castelo dos Sonhos, PA (Johnson et al. 1999), an increasing number of cases have been registered in 12 municipalities located near or around this Highway, in the three states under its influence area. MT ranks fourth in the amount of HPS cases reported in Brazil and first in the Pan Amazon area, with over 168 cases registered between 1999-December of 2009, in about 24 municipalities. PA ranks second in the number of cases in the Amazon region, where all HPS cases reported were located in the influence area of the BR-163 Highway (municipalities of Novo Progresso and Altamira). In both states, HPS cases were correlated to the BR-163 Highway and were clearly associated with agricultural activities, such as special grain production (particularly soybean) and deforestation for wood extraction, which are the most productive economic activities observed around the road in MT and PA. It is noteworthy that the other Amazonian states have reported HPS cases only sporadically, as observed in AM and RO (dos Santos et al. 2006, Rosa et al., unpublished observations).

The population and economic characteristics of the sampling reflect the reality of the entire population living in the four municipalities used in this study and probably also of the other municipalities in the influence area of the BR-163 Highway. The low seroprevalence of $\operatorname{IgG}$ antibodies in the Novo Progresso, Trairão and Guarantã do Norte (ranging from 2.16-4.75\%) is in accordance with the data from Brazilian HPS cases (Holmes et al. 2000, MS/SVS 2009), while in Marcelândia, the seroprevalence was similar to that observed in the Amazon area of MA (Mendes et al. 2001, 2010), as well as in Chile (Castillo et al. 2002) and Paraguay (Ferrer et al. 1998).

The reduced prevalence of IgM antibodies, the detection of IgM antibodies in asymptomatic and oligosymptomatic individuals and the low number of HPS cases reported in the influence area of the BR-163 Highway in comparison to South and Southeast Brazilian Regions, suggest the occurrence of non severe and/or atypical hantaviral infection cases, as well as the possible undernotification of cases in the Amazon region as previously observed by Mendes et al. (2010). Moreover, until now HPS cases have not been diagnosed among people living in Municipality of Trairão. The IgM antibodies detected in an asymptomatic person signifies the recent circulation of hantaviruses in the municipality.

The prevalence of anti-hantavirus IgG antibodies in adult males observed in both sites of PA was similar to those observed in other Brazilian states (Ferreira 2003, Mendes et al. 2004, Elkhoury et al. 2005, MS/SVS 2009, Rosa et al., unpublished observations). Nonetheless, in Guarantã do Norte and Marcelândia sites the highest seroprevalence was observed among women. This fact could be explained by the high number of samples collected from women under spontaneous demand.

In the four sites, although high prevalence was observed in adults, antibodies against hantaviruses were also detected in children, young people and housewives. 
These groups are not often included in hantavirus investigations. An important fact that has been considered is the participation of those groups in the subsistence agriculture in the Amazon region.

Hantavirus IgG antibodies were detected on inhabitants of Novo Progresso, Trairão and Guarantã do Norte along the three periods of collection, suggesting that these places have been continuously exposed to hantaviruses. In Marcelândia municipality, high prevalence was observed during the rainy season. Similar observation has been made in municipality of Anajatuba, MA, Amazon region (Mendes et al. 2001). However, a different antibody profile has been observed in SP, where the highest seroprevalence of hantavirus antibodies occurred during the dry season (Donalisio et al. 2008). This difference could reflect the distinct ecosystems, wild rodent behaviour and economic activities in the Brazilian Amazon region and Southeastern Brazil.

The phylogenetic study confirmed the continuous circulation of CASV in municipality of Altamira since 1995 and its detection in the municipalities of Novo Progresso (PA) and Guarantã do Norte (MT), suggesting that the CASV is the hantavirus associated with HPS cases in the influence area of the BR-163 Highway (Fig. 2). Therefore, the report of the CASV in MT shows the complex ecosystem in this state, which has allowed the circulation of the two different hantaviruses that infect humans: Laguna Negra-like virus associated with Calomys sp., which has been detected in the middle-western region of the state (Rosa et al., unpublished observations) and recognised as the main causative agent of HPS in MT and Castelo dos Sonhos, which has been associated with cases in the northern region of MT and also in PA. A recent study performed by the Instituto Evandro Chagas and the Brazilian Ministry of Health suggests that the possible natural reservoir of the CASV is a rodent from the genus Oligoryzomys (Rosa et al., unpublished observations).

The ongoing detection of HPS cases throughout the years in the influence area of the BR-163 Highway as well as the increase of deforestation for the establishment of agriculture, cattle grazing and wood products exploration raises the possibility of more frequent contact between humans and rodent reservoirs. Consequently, that has increased the risk of the emergence of new hantavirus lineages, the occurrence of more HPS cases and possibly large outbreaks of the disease.

Although these results did not show a significant seroprevalence of antibodies against hantaviruses that characterise serious health problem in the influence area of BR-163 Highway, the occurrence of focal outbreaks and sporadic HPS cases in this area, together with the paving of the Highway in PA, which will be performed in the next years, will probably worsen this public health panorama similarly to what happened in MT. Therefore, the continuity of this study in the influence area of the BR-163 Highway is of fundamental importance to detect early the CASV hantavirus and possibly other indigenous hantaviruses to promote an efficient surveillance, to prevent the occurrence of hantavirus infection in the inhabitants of the municipalities under the influence of the highway and to develop a more specific diagnostic test for this important human pathogen in the Brazilian Amazon region.

\section{ACKNOWLEDGEMENTS}

To the Brazilian Ministry of Health, State Health Surveillance Secretariats of Pará and Mato Grosso and Municipal Health Secretariats of the municipalities of Novo Progresso, Trairão, Guarantã do Norte and Marcelândia, for their support during the collection of specimens for this study, and to the people that accepted to participate in this research.

\section{REFERENCES}

Castillo C, Sanhueza L, Täger M, Muñoz S, Ossa G, Vial P 2002. Seroprevalence of antibodies against hantavirus in 10 communities of the IX Region of Chile where hantavirus infections were diagnosed. Rev Med Chil 130: 251-258.

Donalisio MR, Vasconcelos CH, Pereira LE, Avila AM, Katz G 2008. Climatic aspects in hantavirus transmission areas in São Paulo State, Brazil. Cad Saude Publica 24: 1141-1150.

dos Santos MC, de Lacerda MV, Benedetti SM, Albuquerque BC, de Aguiar Filho AA, da Rosa Elkhoury M, Travassos da Rosa ES, Vasconcelos PF, Medeiros DB, Mourão MP 2006. Human hantavirus infection, Brazilian Amazon. Emerg Infect Dis 12: 1165-1167.

Elkhoury MR, Wada MY, Carmo EH, Luna EJA, Elkhoury ANSM, Teixeira KG, Nunes ML, Barbosa NP, Caldas EP, Caldas ACS, Marques AAR, Brito MG, Rubio GBG, Silva LP, Katz G, Delfino D, Travassos da Rosa ES, Moreira FG. Aspectos epidemiológicos da infecção e da patogenicidade por hantavírus no Brasil (2004). Boletim Eletrônico Epidemiológico [serial on the Internet]: 5(3): [about 5 p.]. Available from: http://www.saude.gov.br/svs.

Felsenstein J 1985. Confidence limits on phylogenies: an approach using the bootstrap. Evolution 39: 783-791.

Ferreira MS 2003. Hantaviroses. Rev Soc Bras Med Trop 36: 81-96.

Ferrer JF, Jonsson CB, Esteban E, Galligan D, Basombrio MA, PeraltaRamos M, Bharadwaj M, Torrez-Martinez N, Callahan J, Segovia A, Hjelle B 1998. High prevalence of hantavirus infection in Indian communities of the Paraguayan and Argentinean Gran Chaco. Am J Trop Med Hyg 59: 438-444.

Figueiredo LT, Campos GM, Rodrigues FB 2001. Síndrome pulmonar e cardiovascular por Hantavirus: aspectos epidemiológicos, clínicos, do diagnóstico laboratorial e do tratamento. Rev Soc Bras Med Trop 34: 13-23.

Holmes R, Boccanera R, Figueiredo LT, Mançano SR, Pane C 2000. Seroprevalence of human hantavirus infection in the Ribeirão Preto region of São Paulo State, Brazil. Emerg Infect Dis 6: 560-561

Huelsenbeck JP, Ronquist F, Nielsen R, Bollback JP 2001. Bayesian inference of phylogeny and its impact on evolutionary biology. Science 14: 2310-2314.

IBGE - Instituto Brasileiro de Geografia e Estatística. Senso estimativo populacional realizado em 2007 [updated 2007; cited 2009 Ago 19]. Available from: http://www.ibge.gov.br/home/.

ICTV - International Committee on Taxonomy of Viruses 2005. Bunyaviridae. In CM Fauquet, MA Mayo, J Maniloff, U Desselberger, LA Ball, Virus taxonomy: classification and nomenclature of viruses. Eighth report of the International Committee on the Taxonomy of Viruses, Elsevier, San Diego, p. 695-723.

Iversson LB, Rosa AP, Rosa MD, Lomar AV, Sasaki GM, LeDuc JW 1994. Infecção humana por hantavírus nas Regiões Sul e Sudeste do Brasil. Rev Assoc Med Bras 40: 85-92. 
Johnson AM, Bowen MD, Ksiazek TG, Williams RJ, Bryan RT, Mills JN, Peters CJ, Nichol ST 1997. Laguna Negra virus associated with HPS in western Paraguay and Bolivia. Virology 238: 115-127.

Johnson AM, de Souza LT, Ferreira IB, Pereira LE, Ksiazek TG, Rollin PE, Peters CJ, Nichol ST 1999. Genetic investigation of novel hantaviruses causing fatal HPS in Brazil. J Med Virol 59: 527-535.

LeDuc JW, Smith GA, Childs JE, Pinheiro FP, Maiztegui JI, Niklasson B, Antoniades A, Robinson DM, Khin M, Shortridge KF, Wooster MT, Elwell MR, Ilbery PLT, Koech D, Rosa EST, Rosen L 1986. Global survey of antibody to Hantaan-related viruses among peridomestic rodents. Bull World Health Organ 64: 139-144.

LeDuc JW, Smith GA, Pinheiro FP, Vasconcelos PF, Rosa ES, Maiztegui JI 1985. Isolation of a Hantaan-related virus from Brazilian rats and serologic evidence of its widespread distribution in South America. Am J Trop Med Hyg 34: 810-815.

Lee HW, Lee PW, Baek LJ, Song CK, Seong IW 1981. Intraspecific transmission of Hantaan virus, etiologic agent of Korean hemorrhagic fever, in the rodent Apodemus agrarius. Am J Trop Med Hyg 30: 1106-1112.

Mendes WS, Aragão NJ, Santos HJ, Raposo L, Vasconcelos PF, Rosa ES, Elkhoury MR 2001. Hantavirus pulmonary syndrome in Anajatuba, Maranhão, Brazil. Rev Inst Med Trop Sao Paulo 43: 237-240.

Mendes WS, da Silva AA, Aragão LF, Aragão NJ, Raposo M de L, Elkhoury MR, Suzuky A, Ferreira IB, de Sousa LT, Pannuti CS 2004. Hantavirus infection in Anajatuba, Maranhão, Brazil. Emerg Infect Dis 10: 1496-1498.

Mendes WS, da Silva AA, Neiva RF, Costa NM, de Assis MS, Vidigal PM, da G L Leite M, da Rosa ES, de A Medeiros DB, de B Simith D, da C Vasconcelos PF 2010. Serologic survey of hantaviruses infection, Brazilian Amazon. Emerg Infect Dis 16: 889-891.

MS/SVS - Ministério da Saúde/Serviço de Vigilância Sanitária 2006. Informe Técnico. Casos de hantaviroses por unidade federada e ano de ocorrência. Brasil, 1993 - novembro de 2006. Tabela COVEV/CGDT/DEVEP/SVS/MS. Available from: http://portal. saude.gov.br/portal/arquivos/pdf/ano07_n06_scp_hanta_br.pdf.
Nichol ST 1999. Genetic analysis of hantaviruses and their host relationships. In JF Saluzzo, B Dodet, Emergence and control of rodent-borne viral diseases, Elsevier, Paris, p. 99-109.

Nichol ST, Spiropoulou CF, Morzunov S, Rollin PE, Ksiazek TG, Feldmann H, Sanchez A, Childs J, Zaki S, Peters CJ 1993. Genetic identification of a hantavirus associated with an outbreak of acute respiratory illness. Science 262: 914-917.

Nunes MRT, Barbosa TFS, Casseb LMN, Nunes-Neto JP, Segura MN, Monteiro HAO, Silva EVP, Casseb SM, Chiang JO, Martins LC, Medeiros DBA, Vasconcelos PFC 2009. Eco-epidemiologia dos arbovírus na área de influência da rodovia Cuiabá-Santarém (BR-163), estado do Pará, Brasil. Cad Saude Publica 25: 2583-2602.

OPAS - Organização Pan Americana da Saúde 1999. Hantavirus em las Americas. Guia para el diagnóstico, el tratamento, la prevención y el control. OPAS, Cuaderno Técnico 47, p. 66.

Padula PJ, Rossi CM, Della Valle MO, Martínez PV, Colavecchia SB, Edelstein A, Miguel SD, Rabinovich RD, Segura EL 2000. Development and evaluation of a solid-phase enzyme immunoassay based on Andes hantavirus recombinant nucleoprotein. $J$ Med Microbiol 49: 149-155.

Posada D, Crandall KA 1998. MODELTEST: testing the model of DNA substitution. Bioinformatics 14: 817-818.

Rosa ES, Mills JN, Padula PJ, Elkhoury MR, Ksiazek TG, Mendes WS, Santos ED, Araújo GC, Martinez VP, Rosa JF, Edelstein A, Vasconcelos PF 2005. Newly recognized hantaviruses associated with hantavirus pulmonary syndrome in Northern Brazil: parcial genetic characterization of viruses and serologic implication of likely reservoirs. Vector Borne Zoonotic Dis 5: 11-19.

Saitou N, Nei M 1987. The neighbor-joining method: a new method for reconstructing phylogenetic trees. Mol Biol Evol 4: 406-425.

Sanger F, Nicklen S, Coulson AR 1977. DNA sequencing with chainterminating inhibitors. Proc Natl Acad Sci USA 74: 5463-5467.

Swofford DL 2003. PAUP-Phylogenetic analysis using parsimony and other methods. Available from: www.sinauer.com/detail. php?id $=8060$. 